\title{
Cost Shock in Public Tenders Impacting the Railway Operator
}

\author{
Špetik Ondřej ${ }^{1 *}$ \\ ${ }^{1}$ Department of Economics, Faculty of Economics and Administration, Masaryk University, Brno, Czech Republic
}

\begin{abstract}
The aim of this paper is to find out whether the cost shocks occur in the passenger rail transport, whether it can cause problems of financing as well as to evaluate the ways which are used by the purchaser of public transport to change the subsidy for carriers in case of cost shock.

Results have shown that costs shocks can negatively impact financing of the subsidised passenger railway transport, so purchasers of the transport services must be extremely cautious in setting the tender documentation. So that purchasers avoid time-inconsistency solution, it is necessary to set the change in the subsidy in the contract. None of the tested clauses used by purchasers is ideal. We can see over-/undercompensation. The clause with $55 \%$ of the consumer price index and $35 \%$ of the change in labour costs in the transport sector reaches better results especially in contracts with vehicles purchased by the carrier.
\end{abstract}

\section{Introduction}

Functioning of subsidised passenger railway transport is undergoing changes not only in the Czech Republic but also in some countries of the European Union. Some routes are tendered or are awarded directly to the private transport operator. From 2019, public tenders be will obligatory with some exceptions [14].

The experience has shown that the call for tender brings certain problems. Purchasers of transport services either do not have any experience or have little experience with it. Criteria can be settled in such a way that they will not optimise the results of the tender. Passenger's preferences or economic possibilities of carriers may not be taken into account. Nevertheless, the criteria must be carefully settled in the tender documentation to reach efficient public spending.

There is only little experience with the call for tender in the railway sector, and most of them ended up unsuccessfully in the Czech Republic (e.g. a tender on the route R 16 Plzeň-Most was rescinded by the Office for the Protection of Competition due to discrimination occurring on the side of some tenderers [20]). There are two successful examples: a tender for three lines in the South Bohemian Region and a tender in the South Moravian Region.

One of the problems which may occur is called "cost shock". It has not been defined in the literature yet. For this paper, we can define it as a significant and unexcepted change of certain costs. Unexcepted means that carriers cannot count with it in competing for tender. The increase of minimum wage for bus drivers in 2017 is a typical cost shock (i.e. real wages increased by $19 \%$ ). The increase of minimum wage caused difficulties in some regions (e.g. some bus carriers had to terminate the contract [8]).

From the perspective of legislation, it is possible to resolve this situation in two ways: ex ante approach when the contract can be changed by the inflation or another clause or ex post approach when the contract can be ad hoc changed after the cost shock. Ex post solution may bring problems with time-inconsistency. Coming back to the example of the increase of minimum wage, purchasers of transport services might not address the problem. It also increases insecurity for carriers.

The topic is also important due to its fiscal consequences. Passenger rail transport is annually subsidised by approximately 0.6 billion Euros [17]. Furthermore, public authorities have a contract by due diligence.

The objective of this paper is to find out whether the cost shocks occur in the passenger rail transport, whether it can cause problems of financing as well as to evaluate the ways which are used by the purchaser of public transport in order to change the subsidy for carriers in case of cost shock.

The structure of the paper corresponds to the objective. After the literature review, we will deal with the possible existence of cost shock in the passenger rail transport. Afterwards, we will focus on its influence on financing of the contract, and then we will evaluate the way the purchasers of the transport change the subsidy.

The methodology is to compare changes in real costs with the changes in the subsidy which is presumed in the contract. We have conducted this analysis on the not electrified, regional routes.

The amount of the costs is based on Šíp [18]. Prices of fuel, the consumer price index (CPI), average wages

* Corresponding author: 405154@mail.muni.cz 
are based on the statistics of the Czech Statistical Office and dates of other average wages derive from the Average Earnings Information System [7].

\section{Literature Review}

Time inconsistency was firstly described by Kydland and Prescott [4, 10]. Time-inconsistent politics is such politics whose ex-ante optimum differ from ex-post optimum [14]. An example of time-inconsistent politics is the patent policy. The government in the time $t$ declares the patent's protection, but in the time $t+s$ does not protect the intellectual property of patents.

In the literature, we can find papers dealing with time inconsistency by the protection of investments. Dastan [3] and Bondarev and Weigt [21] focused on time inconsistency in the energy sector. Nevertheless, the literature has not focused on time inconsistency in public tenders.

The term "cost shock" is a wide term overlapping public transport sector. It is mentioned in relation to the exchange rate risk of multinational corporations. According to these papers, exchange rate movements influence the profit. Several papers deal with cost shock of commodities. They are primarily focused rather than commodity consumers to the mining companies [12].

Regarding the public tenders, literature deals with revenue risks (e.g. Hunold and Wolf [6] or Nigrin [13]). Smith and Wheat (2016) mention cost shocks: they settled them as an important factor influencing the whole railway industry. Uguccioni [19] has focused on costs in the rail freight transport and their structure changes: according to him, wage costs and costs for vehicles have decreased by the time, whereas fuel and the charge of the transport route have increased. $\mathrm{He}$ has explicitly mentioned the shock of increased labour costs because of the trade unions pressure, and he has noted that this growth can exceed an increase of work productivity.

Hammoudeh and $\mathrm{Li}$ [5] studied the influence of increasing oil prices on return on capital investment in the American transport industry. Nandha and Brooks [11] have investigated the relationship between changes in oil prices and return in the transport industry in 38 countries. They have found out that in developed counties there is a negative impact on return on capital investment in the transport sector. The impact of oil shock can differ from a company to company with regard to the fact whether companies can pass on these costs to their customers $[1,15]$.

Velde and Beck [22] analysed why carriers in Germany do not sign up to the public tender even though they collect the tender documentation. He has found out that higher risk relates to lower willingness to participate in the tender. Firstly, there is a cost risk and secondly the revenue risk. According to Hunold and Wolf [6], a suitable setting of the tender conditions has influenced not only the sustainability of the project but also the participation in the public tender and consequently its price, too.

\section{The Existence of the Cost Shock in the Transport}

From the literature review, we can say that the cost shock can influence the profitability of the contract. For our paper, it is necessary to verify the hypothesis of the cost shock existence in the railway passenger sector. Firstly, it is necessary to provide a cost analysis of railway companies. Moreover, the costs can differ from line to line. We have settled the analysis of the line Bratislava-Komárno in Slovakia by Šíp [18] as a measure because of the data availability. This analysis was carried out to award the contract to a private carrier. The analysis calculates with new vehicles on the notelectrified line. We can generalise the results on lines with the similar cost structure.

In the Table no. 1, we can see the costs. The price level is settled in the year 2010, and the net profit is set to $2.8 \%$ in both situations.

Table 1 : Estimated costs on the Bratislava-Komárno line

\begin{tabular}{|c|c|c|c|c|c|}
\hline Item & $\begin{array}{l}\text { Thou } \\
\text { sands } \\
\text { EUR }\end{array}$ & $\begin{array}{l}\mathrm{EU} \\
\mathrm{R} / \mathrm{k} \\
\mathrm{m}\end{array}$ & Share & $\begin{array}{l}\text { Share } \\
\text { without } \\
\text { charge } \\
\text { of the } \\
\text { transpo } \\
\text { rt route }\end{array}$ & $\begin{array}{l}\text { Share } \\
\text { without } \\
\text { charge } \\
\text { of the } \\
\text { transpo } \\
\text { rt route } \\
\text { and } \\
\text { leasing }\end{array}$ \\
\hline $\begin{array}{l}\text { Vehicle } \\
\text { leasing }\end{array}$ & 3061 & 2.45 & $\begin{array}{l}33.2 \\
\%\end{array}$ & $41.3 \%$ & $X$ \\
\hline $\begin{array}{l}\text { Depreciatio } \\
\mathrm{n}\end{array}$ & 172 & 0.14 & $2 \%$ & $2.4 \%$ & $4.2 \%$ \\
\hline Fuel & 1273 & 1.02 & $\begin{array}{l}13.8 \\
\%\end{array}$ & $17.2 \%$ & $30.3 \%$ \\
\hline $\begin{array}{l}\text { Maintenanc } \\
\text { e of vehicles }\end{array}$ & 907 & 0.73 & $9.9 \%$ & $12.3 \%$ & $21.7 \%$ \\
\hline Wages & 800 & 0.64 & $8.7 \%$ & $10.8 \%$ & $19 \%$ \\
\hline $\begin{array}{l}\text { Social } \\
\text { security and } \\
\text { health } \\
\text { insurance } \\
\text { payments }\end{array}$ & 272 & 0.22 & $3 \%$ & $3.7 \%$ & $6.5 \%$ \\
\hline $\begin{array}{l}\text { Other costs } \\
\text { and } \\
\text { administrati } \\
\text { ve costs }\end{array}$ & 652 & 0.52 & $7.1 \%$ & $8.8 \%$ & $15.4 \%$ \\
\hline Profit & 269 & 0.21 & $2.8 \%$ & $3.5 \%$ & $2.8 \%$ \\
\hline $\begin{array}{l}\text { Total costs } \\
\text { (without } \\
\text { charge of } \\
\text { the transport } \\
\text { route) }\end{array}$ & 7405 & 5.93 & $\begin{array}{l}80.4 \\
\%\end{array}$ & $100 \%$ & $100 \%$ \\
\hline $\begin{array}{l}\text { Estimation } \\
\text { of charge of }\end{array}$ & 1818 & 1.45 & $\begin{array}{l}19.6 \\
\%\end{array}$ & $\mathrm{X}$ & $\mathrm{X}$ \\
\hline
\end{tabular}
route (2011) Source: Šíp [18] 
We will concentrate on the proportion of the costs in the total costs. Some regions (e.g. the South Moravian Region) are going to call for tender of the operation and vehicle separately, we will also count with the contract without vehicles [9]. We will focus on costs which can significantly fluctuate. In our case, they are fuel and labour costs (i.e. the sum of wages and social security and health insurance payments).

Looking at the trend in fuel prices, we can see significant fluctuations in both directions.

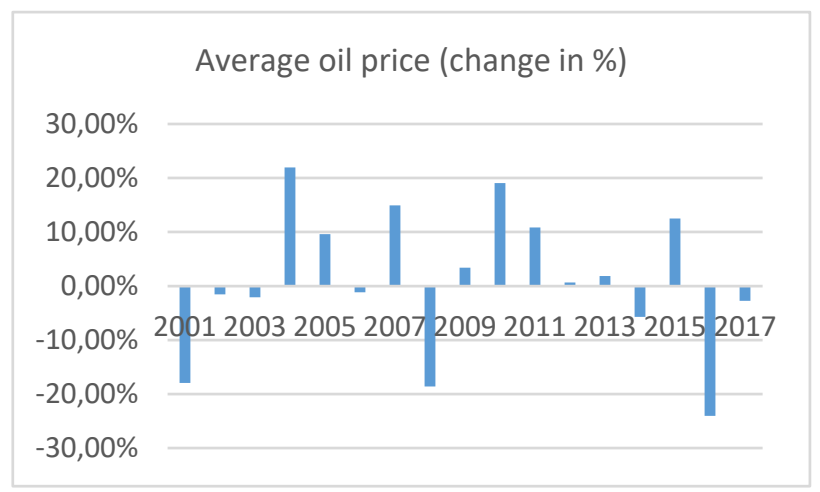

Figure 1: Average oil price

Source: Czech Statistical Office 2018

If we analyse changes in labour costs, we must set up a group of workers whose wage will be examined. The passenger railway transport requires specific employees whose wage development can differ from development in the whole transport industry. Structure of specific employees is indicated in the Table no. 2.

Table 2: Share of the profession on the labour costs

Assistant in the transport $12.16 \%$

Cabin crew $\quad 35.81 \%$

Driver $\quad 45.95 \%$

Traffic controller $\quad 6.08 \%$

Assistant in the transport $\quad 12.16 \%$

Source: Šip [18]

We have taken their average wages from the Average Earnings Information System:

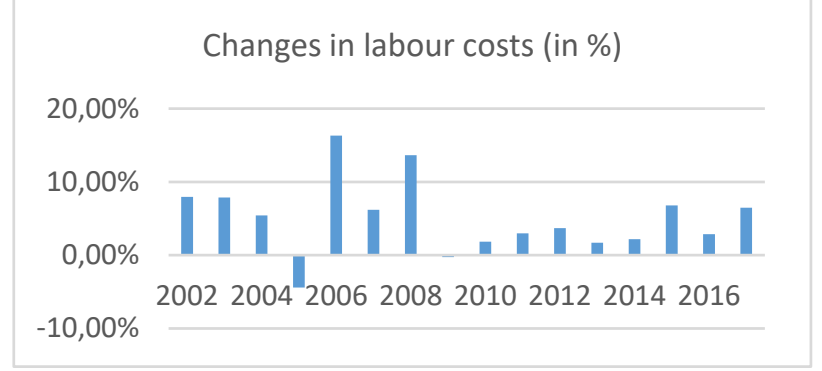

Figure 2: Changes in labour costs

Source: ispv.cz [7]

From the information above, the conclusion is that cost shocks are present. We can see unexpected cost changes especially in the oil prices. In addition, changes in labour cost are significant. Both can negatively influence financing of the subsidised transport services.

\section{Influence of Cost Shocks on Financing of the Transport Services}

Change of the costs as such would not cause the problem of financing the subsidised transport services. It is also important how the change in the costs will influence the total financing of the services: we are looking for the proportion of the changes in the total costs.

In the next charts, the real change in the subsidy is outlined because of the cost increase. Contracts for the passenger rail transport can be concluded for 15 years; we indicate the real change in the subsidy in two-, three-, five-, ten- and fifteen-year moving averages.

We provide all changes for both situations - when vehicles are purchased by the carrier and by a public authority.

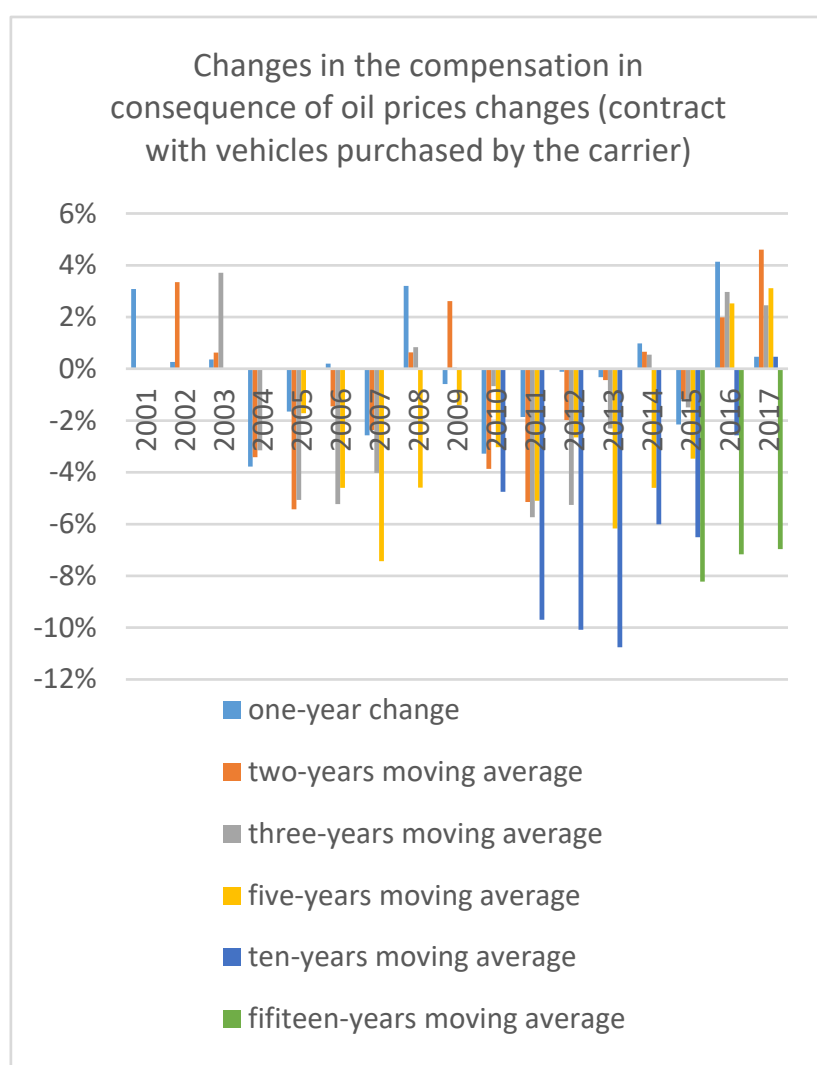

Figure 3: Changes in the compensation in consequence of oil prices changes (contract with vehicles purchased by the carrier) $[2,18]$ 
Change in the subsidy because of oil price changes (contract with vehicles purchased by the public authority)

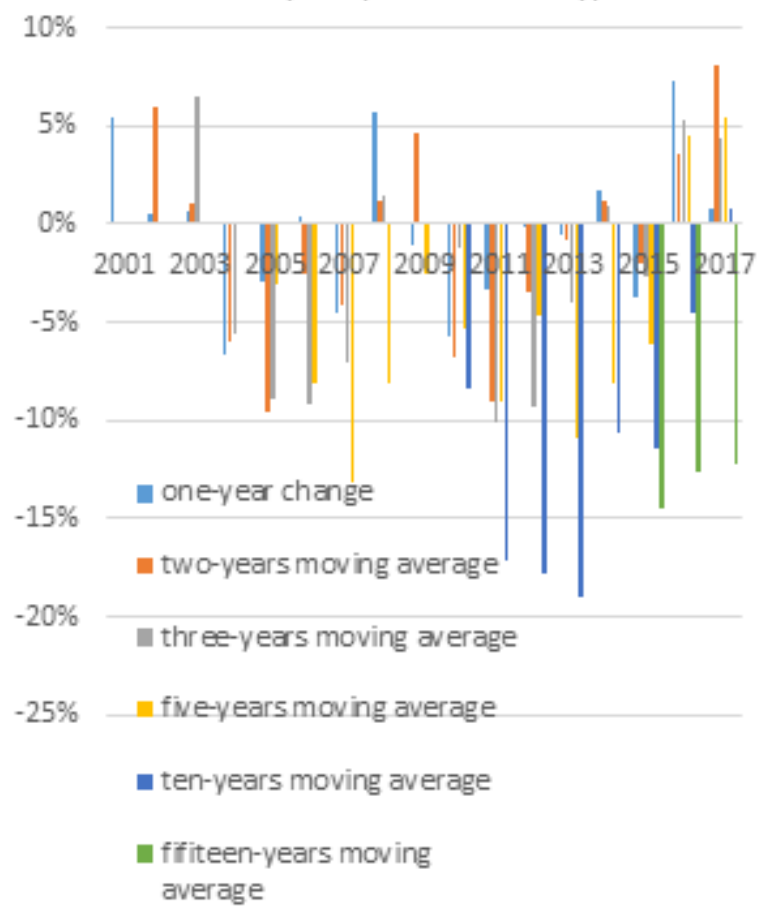

Figure 4: Changes in the compensation in consequence of oil prices changes (contract with vehicles purchased by the public authority) $[2,18]$

In order to analyse the labour costs, we have used costs for workers necessary for transport services.

Change in the compensation in consequence of labour cost changes (contract with vehicles purchased by the carrier)

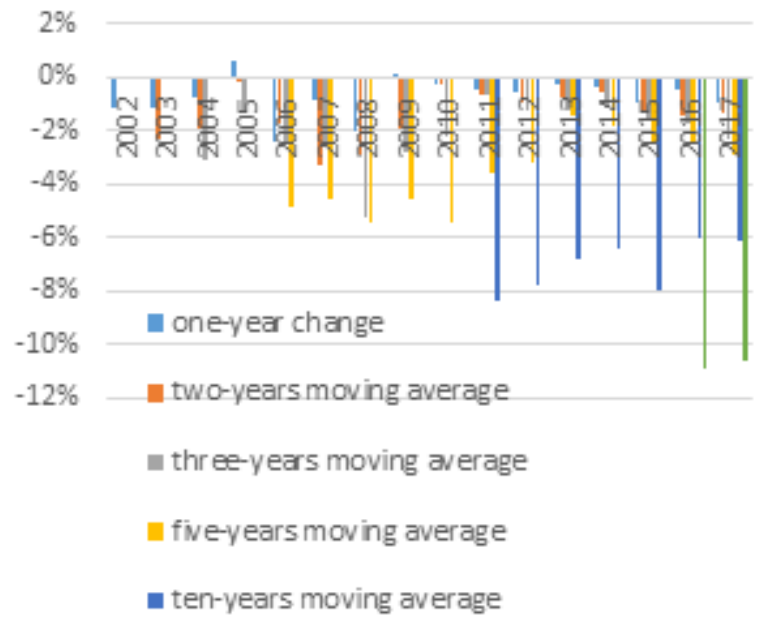

Figure 5 : Change in the compensation in consequence of labour cost changes (contract with vehicles purchased by the carrier) $[2,18]$
Change in the compensation in consequence of labour cost changes (contract with vehicles purchased by the public authority)

$5 \%$

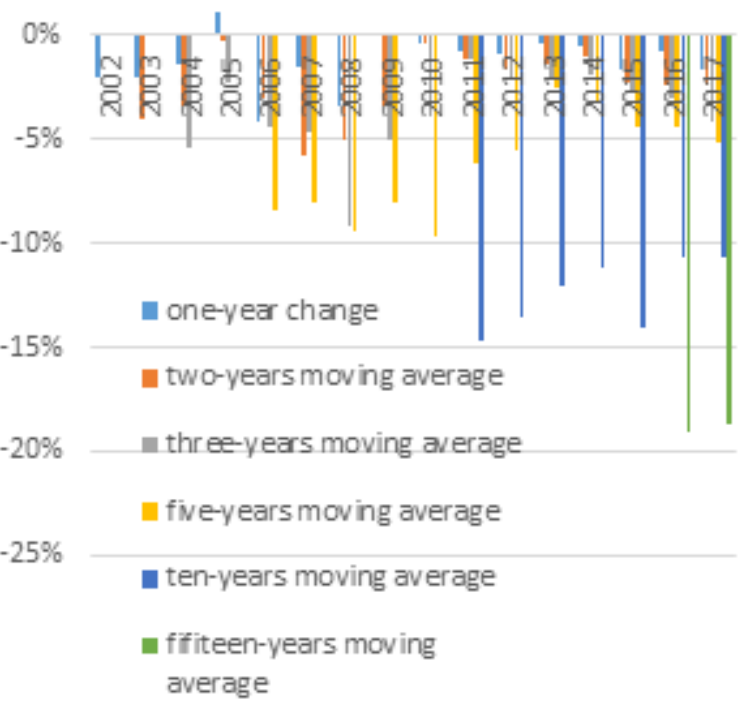

Figure 6: Change in the compensation in consequence of labour cost changes (contract with vehicles purchased by the public authority) $[2,18]$

We have summed up oil price changes and labour cost changes for analysing the real impact on the carrier. The consumer price index has changed other variable costs.

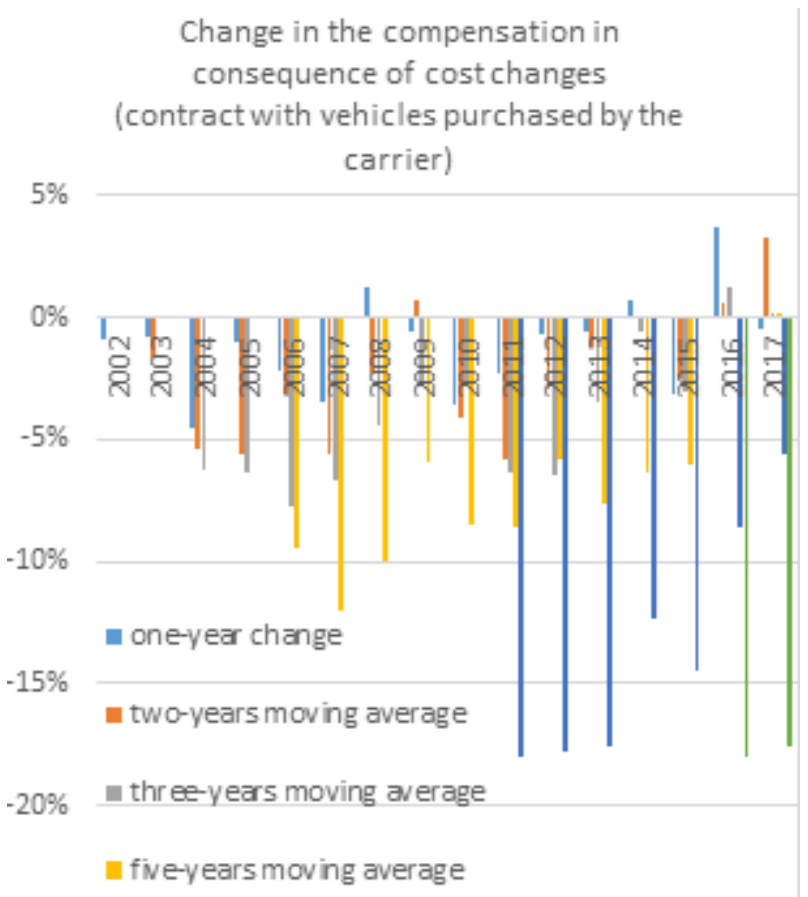

Figure 7: Change in the compensation in consequence of cost changes (contract with vehicles purchased by the carrier) $[2,18]$ 


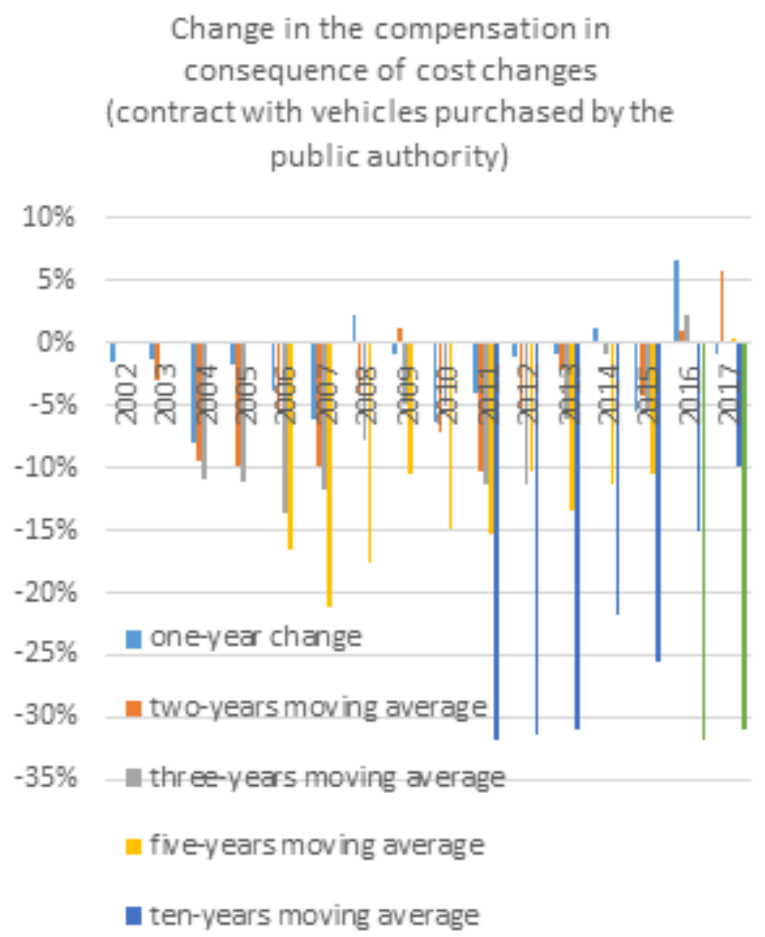

Figure 8: Change in the compensation in consequence of cost changes (contract with vehicles purchased by the public authority $[2,18]$

We can see that changes in costs can have a significant impact on financial sustainability. In case of the contract when the carrier purchases the vehicle, there is lower fluctuation than in case of the contract when the public authority purchases the vehicles. We can see bigger fluctuation in longer period. In case of the contract for ten years when carrier purchases the vehicles, we can see fluctuation from $5.6 \%$ to $18 \%$. In comparison with that, in case of the contract when the public authority purchases the vehicles, we can see fluctuation from 9.9 $\%$ to $31.8 \%$. Carriers face difficult estimation of the future development. To sum it up, changes in costs may negatively impact financing of public transport.

\section{Change in the Subsidy}

We will focus on possible ways to change the subsidy and the established case practice. When the contract is directly awarded, there are no limits for changing the contract. It is possible to approve the amendment and raise the subsidy (there are no limits).

When the contract is tendered, the situation is much more complicated. There are two ways [23]: firstly, in the contract can be a clause (it can be linked to the consumer price index - inflation clause - index of wages, etc.). Secondly, the contract can be modified where the value of the modification is below both of the following values: the thresholds set in the Directive $172 / 2016$ and $10 \%$ of the initial contract value. If the value does not fulfil the thresholds, it is necessary to launch a new procurement procedure [23].

In the next chapters, we will find a solution when the contract may not be terminated due to changes in costs.

\subsection{The Subsidy Changes Set in the Contract}

Inflation clause ranks among the most frequent methods of rising subsidy. Changing subsidy about oil price changes is another way how contracts try to solve cost shocks. We can also find changes in labour costs in the transport sector or changes in wages in the whole economy. In the next table, we can see examples from the bus sector.

Table 3: Change in the subsidy in contracts with bus companies [16]

\begin{tabular}{|c|c|c|c|c|}
\hline Contract & $\begin{array}{l}\text { Inflatio } \\
\mathrm{n} \\
\text { clause }\end{array}$ & $\begin{array}{l}\text { Chang } \\
\text { es in } \\
\text { oil } \\
\text { price }\end{array}$ & $\begin{array}{l}\text { Change } \\
\mathrm{s} \text { in the } \\
\text { labour } \\
\text { costs in } \\
\text { the } \\
\text { transpo } \\
\mathrm{rt} \\
\text { sector }\end{array}$ & $\begin{array}{l}\text { Change } \\
\mathrm{s} \text { in the } \\
\text { averag } \\
\mathrm{e} \\
\text { wages }\end{array}$ \\
\hline Zdar & $66 \%$ & $24 \%$ & & \\
\hline $\begin{array}{l}\text { BORS } \\
\text { VYDOS }\end{array}$ & $30 \%$ & $28 \%$ & $27 \%$ & \\
\hline (Jihovýchod & $30 \%$ & $28 \%$ & $27 \%$ & \\
\hline $\begin{array}{l}\text { VYDOS } \\
\text { (Brněnsko) }\end{array}$ & $66 \%$ & $24 \%$ & & \\
\hline $\begin{array}{l}\text { Chomutovs } \\
\text { ko }\end{array}$ & & $30 \%$ & & $30 \%$ \\
\hline Litoměřicko & & $32 \%$ & & $32 \%$ \\
\hline Podbořansk & & $31 \%$ & & $31 \%$ \\
\hline
\end{tabular}

Directly awarded contracts do not usually have any clauses (e. g. contract no. S-OD/2009/05-VI-IDS).

In the next table, we can see the situation in the railway sector.

Table 4: Change in the subsidy in contracts with railway companies [16]

\begin{tabular}{|c|c|c|c|c|c|}
\hline $\begin{array}{l}\text { Contra } \\
\text { ct }\end{array}$ & $\begin{array}{l}\text { Inflation } \\
\text { clause }\end{array}$ & $\begin{array}{l}\text { Chan } \\
\text { ges in } \\
\text { VAT }\end{array}$ & $\begin{array}{l}\text { Chan } \\
\text { ges in } \\
\text { oil } \\
\text { price }\end{array}$ & $\begin{array}{l}\text { Chang } \\
\text { es in } \\
\text { the } \\
\text { labour } \\
\text { cost in } \\
\text { the } \\
\text { transp } \\
\text { ort } \\
\text { sector }\end{array}$ & $\begin{array}{l}\text { Transp } \\
\text { ort } \\
\text { route }\end{array}$ \\
\hline $\begin{array}{l}\text { GW } \\
\text { Train } \\
\text { Regio } \\
\text { (R 25) }\end{array}$ & $\begin{array}{l}100 \% \\
\text { minus } \\
\text { amortisat } \\
\text { ion }\end{array}$ & & & & $\begin{array}{l}\text { The } \\
\text { full } \\
\text { costs }\end{array}$ \\
\hline $\begin{array}{l}\text { GW } \\
\text { Train } \\
\text { Regio } \\
\text { Pošum } \\
\text { aví }\end{array}$ & $100 \%$ & $50 \%$ & $\begin{array}{l}\text { Chan } \\
\text { ges in } \\
\text { costs } \\
\text { for oil } \\
\text { minus } \\
\text { CPI }\end{array}$ & & $\begin{array}{l}\text { The } \\
\text { full } \\
\text { costs }\end{array}$ \\
\hline $\begin{array}{l}\text { RegioJ } \\
\text { et (SK) }\end{array}$ & $100 \%$ & & & & $\begin{array}{l}\text { The } \\
\text { full }\end{array}$ \\
\hline
\end{tabular}




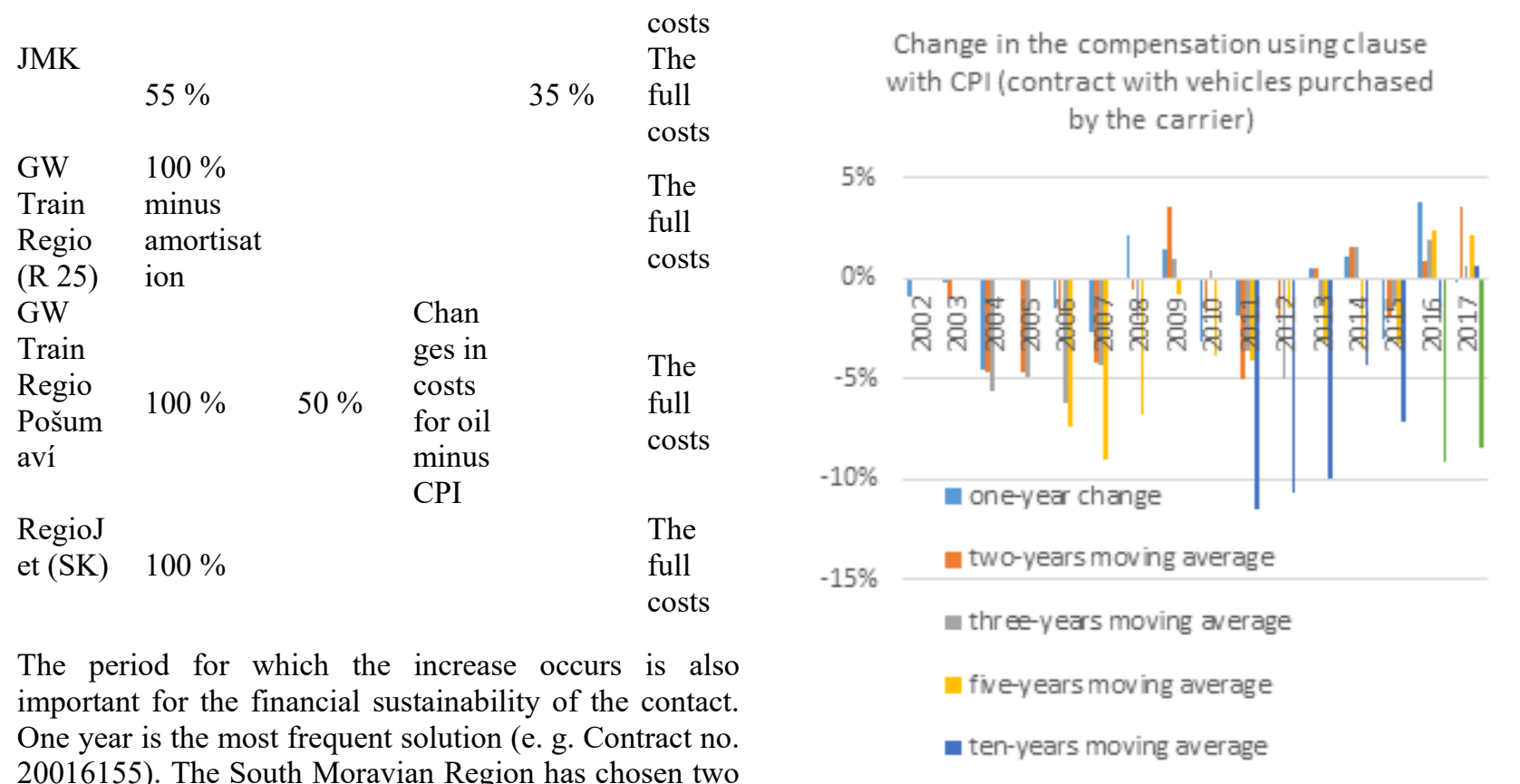
20016155). The South Moravian Region has chosen two years in the new contract with Czech Railways.

\subsection{The Subsidy Rising by Modification of the Contract}

Modification of the contract is the second solution. All modifications must fulfil legal requirements. All additional subsidies may not exceed $10 \%$ of the contract, and the amount may not exceed 5.7 mil. CZK [24].

In this case, carriers face the risk of timeinconsistency behaviour of purchasers. If the purchasers target is to minimise the budgetary impact, they do not want to increase the subsidy because of the cost shock. Furthermore, the railway sector is rather specific: it is much more difficult to transfer fix costs to another business than in the bus sector (e.g. it is more difficult to sell a locomotive than a bus).

\section{Setting the Subsidy}

We will deal with how the purchaser should set the tender documentation so that the contract is financially sustainable and the carriers do not face time inconsistency. We will test the influence of different types of clauses on the financial sustainability of the contract.

We will assume that purchasers can identify the structure of the costs. It is a reasonable assumption because purchasers must estimate the value of the contracts.

Time consistency is such a solution which presumes a change in the subsidy set in the contract. Therefore, we will seek a solution with subsidy changes set in the contract, not in the form of a modification of the contract.

Firstly, we will test the subsidy change according to the consumer price index rise delayed by one year.

Figure 9: Change in the compensation using clause with CPI (contract with vehicles purchased by the carrier) [2, 18]

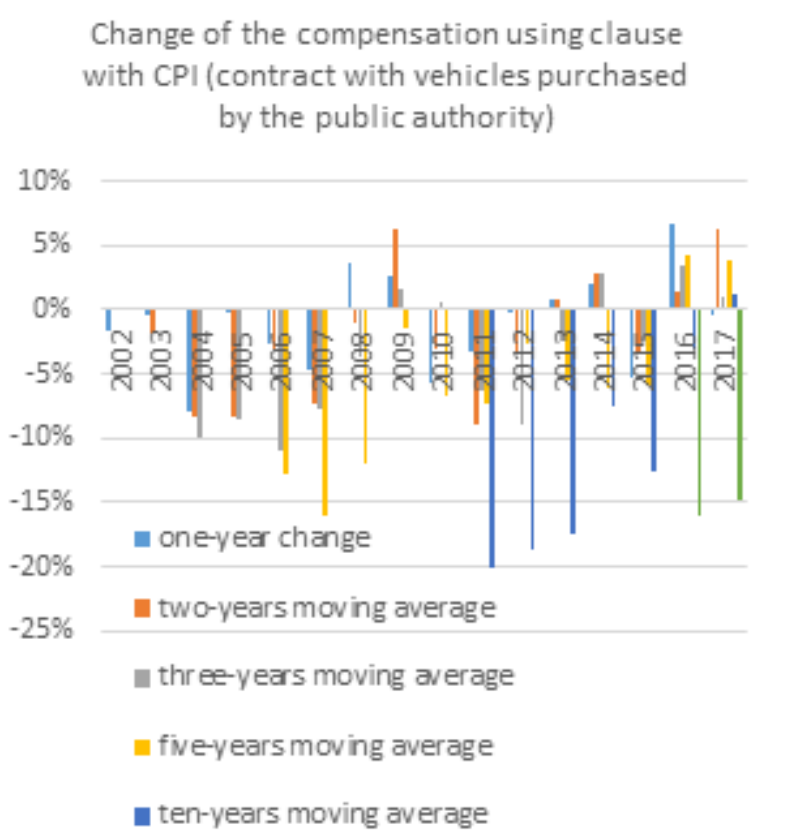

Figure 10: Change of the compensation using clause with CPI (contract with vehicles purchased by the public authority) $[2,18]$

Figures provide an overview of different conclusion with utilization of the consumer price index. In case when carriers purchase the vehicles, it is possible to say that the real value of subsidy increases up to $12 \%$. The case when public authorities purchase the vehicles allows arriving at a different conclusion. The real value of the subsidy is reduced to the extent of up to $20 \%$ in 10 years.

In the next chart, we have included the change in labour costs in the transport sector. The Czech Statistical Office has published this statistic. The chart below 
includes $55 \%$ of the consumer price index and $35 \%$ of the change in labour costs in the transport sector.

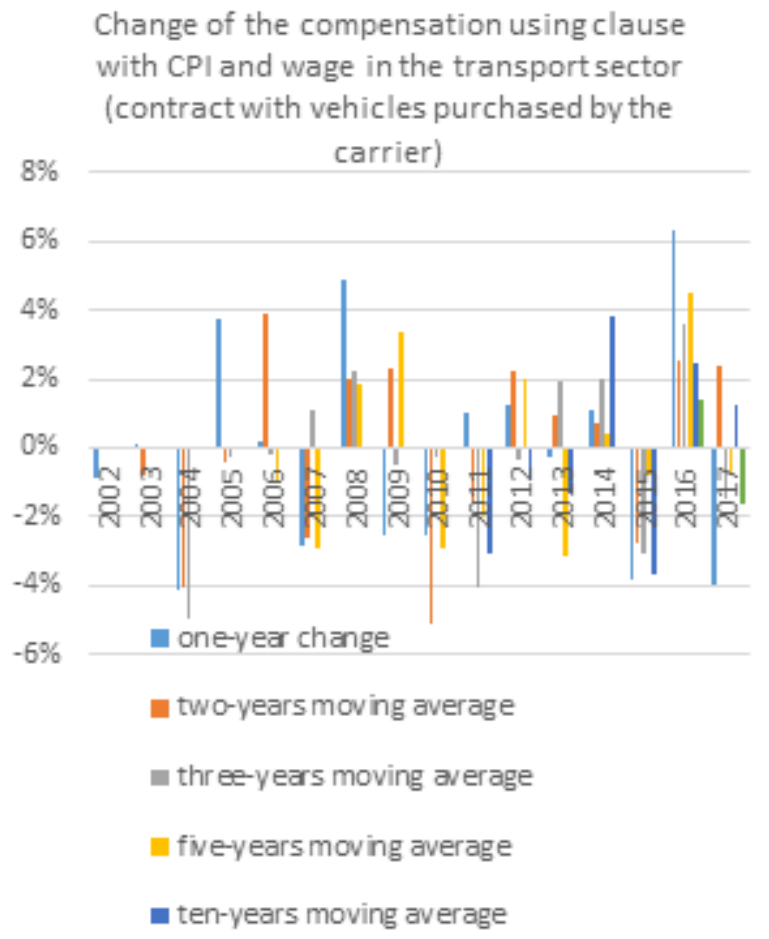

Figure 11: Change of the compensation using clause with CPI and wage in the transport sector (contract with vehicles purchased by the carrier) $[2,18]$

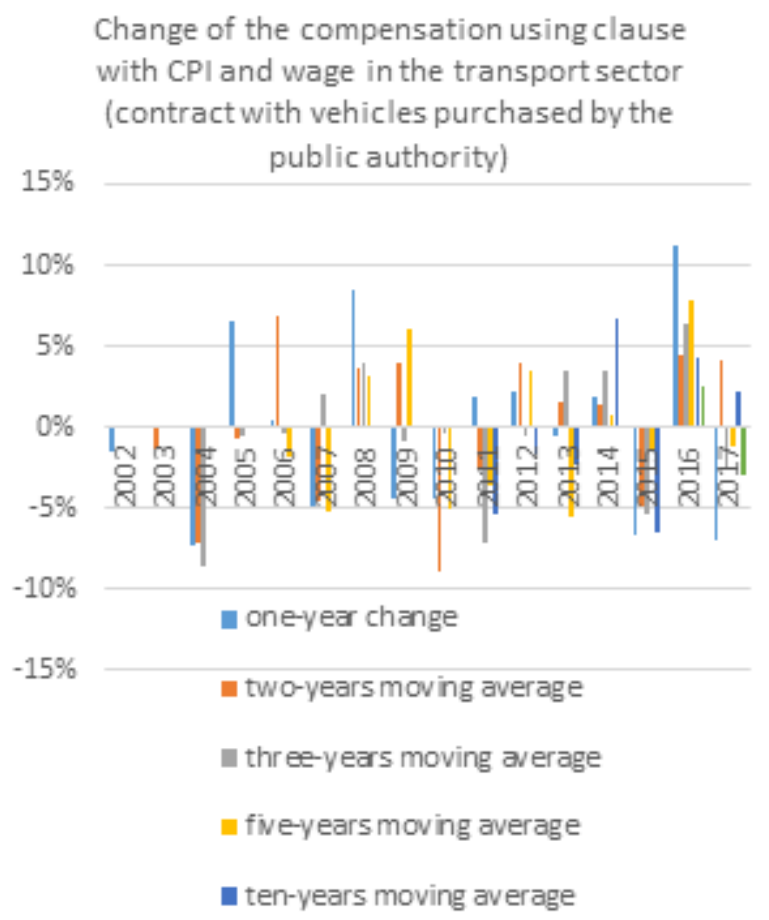

Figure 12: Change of the compensation using clause with CPI and wage in the transport sector (contract with vehicles purchased by the public authority) $[2,18]$
When the carriers purchase vehicles, contracts reach better results than with using only consumer price index, the 10 -year's increasing of subsidy may be up to $4 \%$. For contracts when public authorities purchase the vehicles also reach better results. Although, the results are not as good as in the first mentioned contracts, volatility is up to $10 \%$ with one exemption in 2016.

\section{Conclusion}

Cost shocks can negatively impact financing of the subsidised passenger railway transport. We can observe fluctuations especially in the oil prices in both directions. Labour costs fluctuations are not so noticeable as oil prices, but they can also negatively impact financing. Purchasers of the transport services have to be extremely cautious in setting the tender documentation.

So that purchasers avoid time-inconsistency solution, it is necessary to set the change in the subsidy in the contract. None of the tested clauses used by purchasers is ideal. We can see over-/under-compensation. The inflation clause does not reach good results. In the contract with vehicles purchased by the carrier we can see real decreasing of the subsidy by almost $12 \%$ in ten years. The situation in the contracts with vehicles purchased by the public authority we can see much worse results. The real value of the subsidy has diminished by $20 \%$ in ten years.

The clause with $55 \%$ of the consumer price index and $35 \%$ of the change in labour costs in the transport sector reaches better results especially in contracts with vehicles purchased by the carrier (10-year's increasing of subsidy may be up to $4 \%$ ). In the contracts with vehicles purchased by the public authority we can see 10 -year's increasing of subsidy up to $6 \%$.

This article is the output of the project called "New Mobility High-Speed Transport Systems and Transport-Related Human Behaviour", Reg. No. CCZ.02.1.01/0.0/0.0/16 026/0008430, co-financed by the "Operational Programme Research, Development and Education" and it is output of the project called "Specific Research, no. MUNI/A/1133/2017.

\section{References}

1. M. Boyer, M. Martin, D. Filion, Energy Enonomics, 29, 428-453 (2007)

2. ČSÚ [Czech Statistical Office]. ČR od roku 1989 $v$ čislech [online]. 2018[cit. 2018-10-01]. Available from: https://www.czso.cz/csu/czso/ceskarepublika-od-roku-1989-v-cislech-20178jcopi31rm\#03

3. S. Dastan, Renewable and Sustainable Energy Reviews, 59, 958-997(2016)

4. DRAZEN, Allan. Political economy in macroeconomics. Princeton, (2002).

5. S. Hammoudeh, H. Li, Journal of Economics and Business, 57, 1-21 (2005)

6. M. Hunold, Ch. Wolf, Competitive procurement design. ZEW discussion papers (2013) 
7. ISPV.CZ. Quarterly Survey of Average Earnings [online]. 2002-2017 [cit. 2018-10-01]. Available from: https://www.ispv.cz/en/ispvresults/archive.aspx

8. Z. Jarolim. E-mail communication 2018.

9. JIHOMORAVSKÝ KRAJ. Veřejná zakázka: Poskytování veřejných služeb $\mathrm{v}$ přepravě cestujících v regionální železniční osobní dopravě [online]. 2018 Available from: https://zakazky.krajbezkorupce.cz/contract_display 12923.html

10. F. Kydland, E. Prescott, Journal of Political Economy, 85, 473-491 (1977).

11. N. Mohan, R. Brooks, Review of Quantitative Finance and Accounting, 33, 393-409 (2009)

12. L. Cerna, A. Dolinayova, J. Danis. Transport means 2016 : proceedings of the 20th international scientific conference. 414-419 (2016).

13. S. Mohanty, M. Nandha, Financial Review, 46, 465191, 2011

14. T. Nigrin, Z. Tomeš, D. Seidenglanz, P. Mlsna, J. Dujka, Železniční reforma v Německu. (2017).

15. M. Petr, European Networks Law and Regulation Quarterly, 4, 88-97 (2016)

16. S. Raigopal, The Accounting Review, 74, 251-280, 1999.

17. Registry of contracts. Registr smluv [online]. 2018. Available from: https://smlouvy.gov.cz/
18. The Ministry of Transport. Transport Statistics. 2016 Available from: https://www.mdcr.cz/Statistiky/Souhrnneukazatele/Souhrnne-ukazatele-ekonomikydopravniho-sektoru/Dotace-do-pravidelne-verejneprepravy-osob

19. E. Š́p. Analýza nákladov prevádzky vlakov verejnej regionálnej kolajovej dopravy na trati Bratislava hlavná stanice - Komárno. (2010).

20. J. Uguccioni, UGUCCIONI, International Productivity Monitor (2016)

21. UOHS. Decision S0585/2015/VZ37580/2015/532/KST, (2016) Available from: http:/www.uohs.cz/cs/verejne-zakazky/sbirkyrozhodnuti/detail-13933.html

22. A. Bondarev, H. Weigt, Energy Policy, 119, 196205, (2018)

23. A. Dolinayova. Sustainable rail transport: proceedings of railNewcastle talks 2016. 31-44 (2018).

24. D. Velde, A. Beck, Research in Transportation Economics, 29, 145-151, (2010)

25. Directive 2014/24/EU of 26 February 2014 on public procurement. Available from: https://eurlex.europa.eu/legalcontent/EN/TXT/?uri=celex\%3A32014L0024

26. Nařízení vlády č. 172/2016 Sb., o stanovení finančních limitů a částek pro účely zákona o zadávání veřejných zakázek. In: Zákony pro lidi.cz. Available from: https://www.zakonyprolidi.cz/cs/2016$\underline{172 \# \mathrm{f} 5824225}$ 